\begin{tabular}{|l|l|l|l|l|l|}
\hline MUNIBE Antropologia-Arkeologia & $n^{\circ} 70$ & $65-71$ & DONOSTIA & 2019 & ISSN 1132-2217 • eISSN 2172-4555 \\
\hline
\end{tabular}

\title{
Coming back to Ekain (Deba, Gipuzkoa): a new Upper Palaeolithic graphic ensemble in the Erdibide Passage
}

\author{
Retorno a Ekain (Deba, Gipuzkoa): \\ un nuevo conjunto gráfico paleolítico en la galería Erdibide
}

KEY WORDS: Upper Palaeolithic, Rock art, Bison, Magdalenian, Cultural Networks, Cantabrian Region.

PALABRAS CLAVES: Paleolítico superior, Arte rupestre, Bisonte, Magdaleniense, Redes culturales, Región Cantábrica.

GAKO-HITZAK: Goi Paleolitoa, Labar-artea, Bisontea, Madeleine aldia, Sare kulturalak, Kantaurialdea.

Blanca OCHOA(1), Irene VIGIOLA-TOÑA(2) \& Marcos GARCÍA-DIEZ( $^{(3)}$

\begin{abstract}
Ekain cave (Deba, Gipuzkoa) has been researched for the last five decades and has been kept closed to the general public. This fact has allowed an exceptional preservation of the depictions. The re-study of rock art sites discovered during the 20th century and the improvement of the survey and recording methodologies are allowing significant advances in the Upper Palaeolithic research. In this paper we present a new graphic ensemble in the entrance gallery to Ekain cave, also known as Erdibide. We located several pigment stains, a triangular sign and an incomplete depiction of a bison, all drawn in red. This taxon is not new in the cave: other bison have previously been registered in black, red or even engraved; they are incomplete and, in general, lack internal details. Because of this there is a contrast with the horses, technically and stylistically more elaborated. The style of these bison, ascribed mostly to the Niaux morphotype, allows to associate them to the middle-to-late Magdalenian and would, probably, be culturally synchronic to the horses that characterise the cave.
\end{abstract}

\section{RESUMEN}

La cueva de Ekain (Deba, Gipuzkoa) ha sido estudiada durante las últimas cinco décadas y se ha mantenido cerrada al público general por motivos de conservación, hecho que ha permitido que las grafías se preserven de una manera excepcional. El re-estudio de los conjuntos descubiertos durante el siglo XX junto con la mejora de los métodos de prospección y registro está permitiendo nuevos avances en la investigación del arte paleolítico cantábrico. En este artículo presentamos un nuevo conjunto gráfico descubierto en la galería de entrada a la cueva de Ekain conocida como Erdibide. Se han localizado restos de pigmento, un signo triangular y una representación parcial de bisonte en color rojo. Este taxón no constituye una representación nueva en la cueva. Se han registrado previamente otros, tanto pintados en negro o en rojo e incluso grabados; se caracterizan por estar incompletos y carecer, prácticamente, de detalles internos, hecho que contrasta con los cabaIlos, técnica y estilísticamente más elaborados. El estilo característico de estos bisontes, adscritos al tipo Niaux, permite asociarlos a la fase media-avanzada del Magdaleniense y serían, muy probablemente, culturalmente sincrónicos al numeroso conjunto de caballos de la cueva.

\section{LABURPENA}

Ekaingo leizea (Deba, Gipuzkoa) azken bost hamarkadatan aztertu izan da eta publikoarentzako itxita egon da kontserbazio-arrazoiak direla-eta. Horri esker, grafiak bikain zainduta daude. XX. mendean aurkitutako multzoak berraztertu egin dira eta, aldi berean, hobetu egin dira zulaketarako eta erregistrorako metodoak. Horiei esker, aurrerapen berriak egin dira Paleolitoko arte kantauriarraren ikerketan. Artikulu honetan, Ekaingo leizearen sarrerako galerian, Erdibide izenekoan, aurkitutako multzo grafiko berria aurkeztuko dugu. Pigmentu-hondarrak, ikur triangeluar bat eta bisonte baten zati baten errepresentazioa, gorria, aurkitu dira. Taxon hori ez da leizeko errepresentazio berri bat. Aurrez, beltzez edo gorriz margotutako beste batzuk ere erregistratuta daude; baita grabatuak ere. Osatu gabe daude eta ez dute ia barneko xehetasunik, zaldietan ez bezala; izan ere, zaldien irudiak, teknikoki eta estilistikoki, landuagoak dira. Bisonte horien estilo bereizgarriak, Niaux estiloak, aukera ematen du irudiak Madeleine aldiaren erdialdeko fasearekin edo fase aurreratuarekin lotzeko eta, seguru asko, leizeko zaldi kopuru handiaren sinkroniko izango ziren kulturalki.

\section{INTRODUCTION}

Ekain Cave is in Deba (Gipuzkoa) in the north of the Iberian Peninsula (Fig. 1). In 2008, due to its outstanding Palaeolithic cave art ensemble, it was inscribed in
UNESCO's World Heritage List (García-Diez, 2009). The cave has been studied over the course of many years. The first Palaeolithic paintings were discovered in 1969 by members of the Antxieta Arkeologi taldea group du-

\footnotetext{
(1) Departamento de Geografía, Prehistoria y Arqueología. Universidad del País Vasco (UPV/EHU) c/ Tomás y Valiente s/n. 01006 Vitoria. Department of Archaeology. Durham University, South Road, Durham, DH1 3LE (UK). Email: blanca.ochoa@ehu.eus

(2) Departamento de Geografía, Prehistoria y Arqueología. Universidad del País Vasco (UPV/EHU). Email: irene.vigiola@ehu.eus

(3) Departamento de Prehistoria, Historia Antigua y Arqueología. Universidad Complutense de Madrid (UCM), Edificio B. c/ Profesor Aranguren s/n 28040 Madrid, Spain. Email: diez.garcia.marcos@gmail.com
} 
ring their speleological and archaeological exploration of the cave. Since then, numerous researchers have published general studies of the parietal art (Barandiarán, 1969; Altuna \& Apellániz, 1978; Altuna, 1997) and of the excavation in the cave (Altuna \& Merino, 1984). More specific studies have focused on different aspects of the ensembles within the context of Palaeolithic art in northern Spain (Barandiarán, 1974) or have made known occasional new finds (González-Sainz, Cacho, Altuna, 1999; Altuna \& Mariezkurrena, 2009; Ochoa et al. 2018).

Despite all this, studies carried out in the course of nearly fifty years, the methodological advances in research still allow to make new discoveries. In this regard, new techniques in lighting and the processing of digital images is making the identification of figures possible where only simple stains of pigment in a poor state of conservation had been observed. In consequence, the application of these techniques to sites that have been known for decades allow to increase the number of graphic representations and expand our knowledge of Palaeolithic parietal art.
In the framework of a project studying a small group of new Palaeolithic digital representations in the final part of the cave (Ochoa et al., 2018), some remains of red pigment were noticed and, after careful observation, it was concluded that they might form a figure. The present study will describe this new graphic grouping near the entrance of the cave, in a sector where no motifs had been identified before. It consists of a figurative depiction, a bison, a pseudo-triangular motif, and other concentrations of pigment in a deficient state of conservation. We will also reflect on the implications of this graphic ensemble within the particular knowledge of the cave and in the wider context of the graphic territorialities of Palaeolithic societies in the Cantabrian region.

\section{METHODOLOGY}

The fieldwork carried out in Ekain Cave followed the methodology proposed by García-Diez and Ochoa (2013). For the exploration of the cave and the photography we used portable LED illumination so that the angle of the light could be altered in order to identify
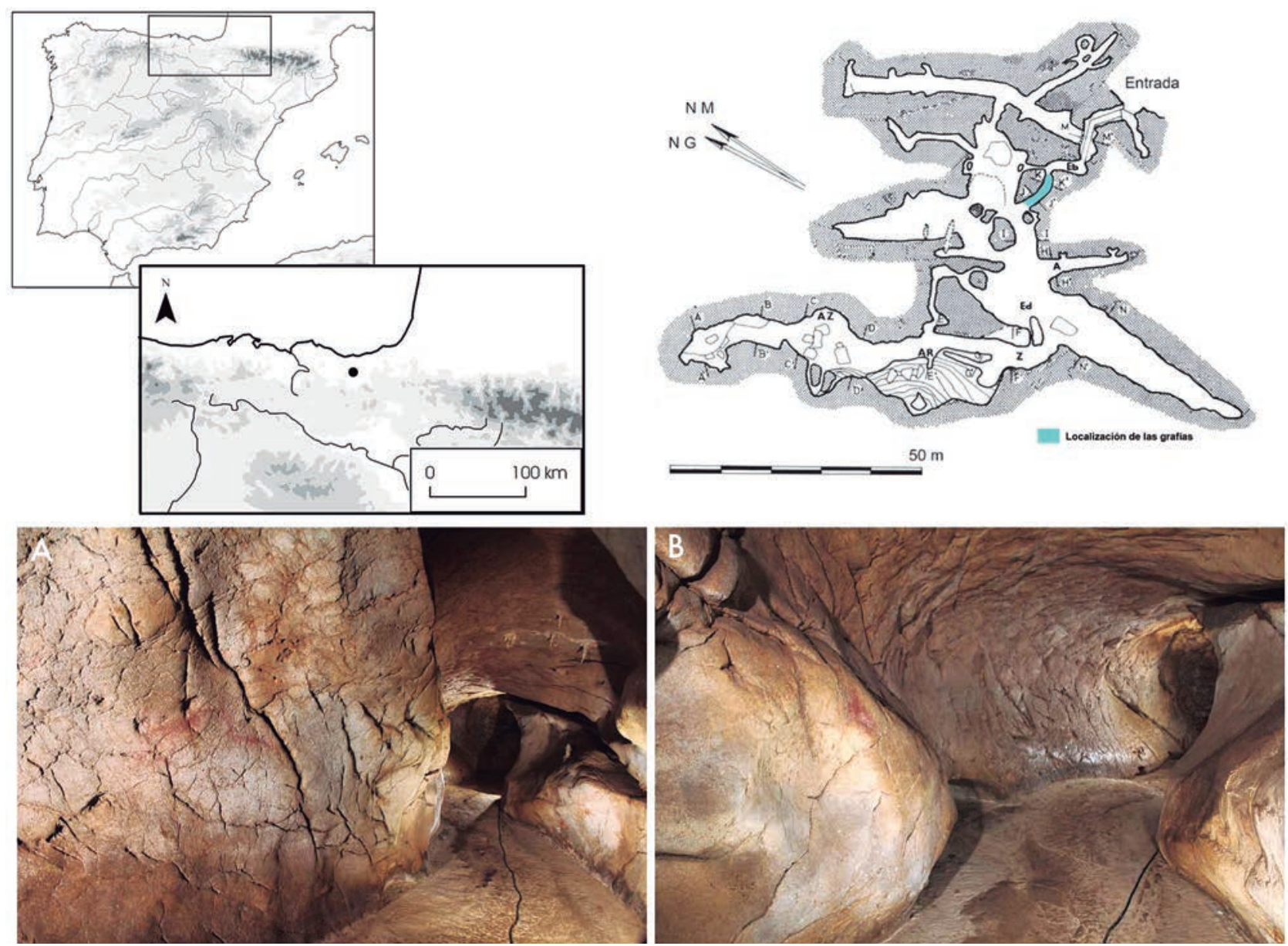

Fig. 1. Location of Ekain cave (Deba, Gipuzkoa); (modified from Altuna and Apellániz, 1978) topography of the cave with location of the new finds and views of the graphic ensemble. / Localización geográfica de la Cueva de Ekain (Deba, Gipuzkoa); (modificado de Altuna y Apellániz, 1978) topografía de la cueva con indicación del nuevo conjunto gráfico y diferentes visiones de la galería Erdibide. 
representations in a poor state of conservation or any fine engravings.

Written documentation was systematically collected for each of the graphic units. The tracings of each representation were based on photographs taken immediately in front of the motif. The original photographs were then enhanced with Adobe Photoshop CS5 $\AA$ and the $D$-Stretch $\otimes$ plug-in for Image $\Theta$. Then tracings were made over the photograph in the cave to avoid subjectivity as much as possible. A digital copy was subsequently made in Adobe Photoshop CS5 $\AA$ using this preliminary version and it was again verified, as many times deemed necessary in the cave, to reduce potential subjectivity. The composition of the definitive version of the tracings include references to the shape of the cave wall and a scale.

\section{DESCRIPTION OF THE ICONOGRAPHIC EN- SEMBLE}

The graphic units are located after the second access gate, $30 \mathrm{~m}$ from the entrance, in the main passage of the cave. This is initially oriented towards the north and after a couple of metres turns west. At this point the passage starts to slope upwards and is relatively narrow (between 1,6 $\mathrm{m}$ and $2 \mathrm{~m}$ ) (Fig. 1). The floor is made of calcite. The panel with the graphic units is on the north wall of this passage. It is a place of access to the interior of the cave and, despite the major efforts to protect the cave, oblivious to the presence of rock art in this particular surface, visitors have rubbed against the wall. As a result, the state of conservation is deficient: mud has been deposited on the rock, probably from the visitors' clothing or hands or owing to natural processes in the cave. The graphic units that have been studied are as follows:

Graphic unit 1 (Fig. 2). Located on the right-hand wall, $30 \mathrm{~m}$ from the entrance and $100 \mathrm{~cm}$ above the floor. The limestone wall is vertical and the surface is flat and smooth.

This graphic unit is a geometric motif with a pseudo-triangular shape. The pigment is distributed over a maximum area of $12 \mathrm{~cm}$ wide and $21 \mathrm{~cm}$ high. The technique used was drawing in red. A precise identification is hindered by its state of conservation.

Graphic unit 2. On the right-hand wall, $195 \mathrm{~cm}$ from the previous graphic unit and $100 \mathrm{~cm}$ above the floor, it is located on a vertical limestone surface that is sinuous and rough with numerous fissures.

This graphic unit is a concentration of pigment whose edges are hard to define because of its state of conservation. The pigment covers a maximum area 108 $\mathrm{cm}$ wide and $51 \mathrm{~cm}$ high. It is an area on the right-hand wall with small concentrations of red pigment. At least three irregular dots, no more than $1.5 \mathrm{~cm}$ in diameter; a convex linear form with a maximum length of $24 \mathrm{~cm}$; and other smaller concentrations can be recognised. The relationship between them cannot be determined. The technique is drawing in red.

Graphic unit 3 (Fig. 3). This is located $1.5 \mathrm{~m}$ above the previous graphic unit, $100 \mathrm{~cm}$ above the floor and $2 \mathrm{~m}$ from the junction with the passage that leads to the Erdialde chamber. The limestone surface is vertical and convex.

This graphic unit is a zoomorph that represents a bison. It consists of the head (naso-frontal line and start of the maxilla), eye, horns, hump, cervical-dorsal line and start of the rump. It faces left and its levelling is $90^{\circ}$. Its maximum dimensions are $33 \mathrm{~cm}$ in height and $74 \mathrm{~cm}$ in length. The zoometric measurements are: lower part of the head to the end of the cervical-dorsal line, $70 \mathrm{~cm}$; posterior horn, $12.5 \mathrm{~cm}$; and anterior horn, $20 \mathrm{~cm}$. It was drawn in red, possibly with a pigment pencil, but this cannot be determined with greater precision owing to the state of conservation.

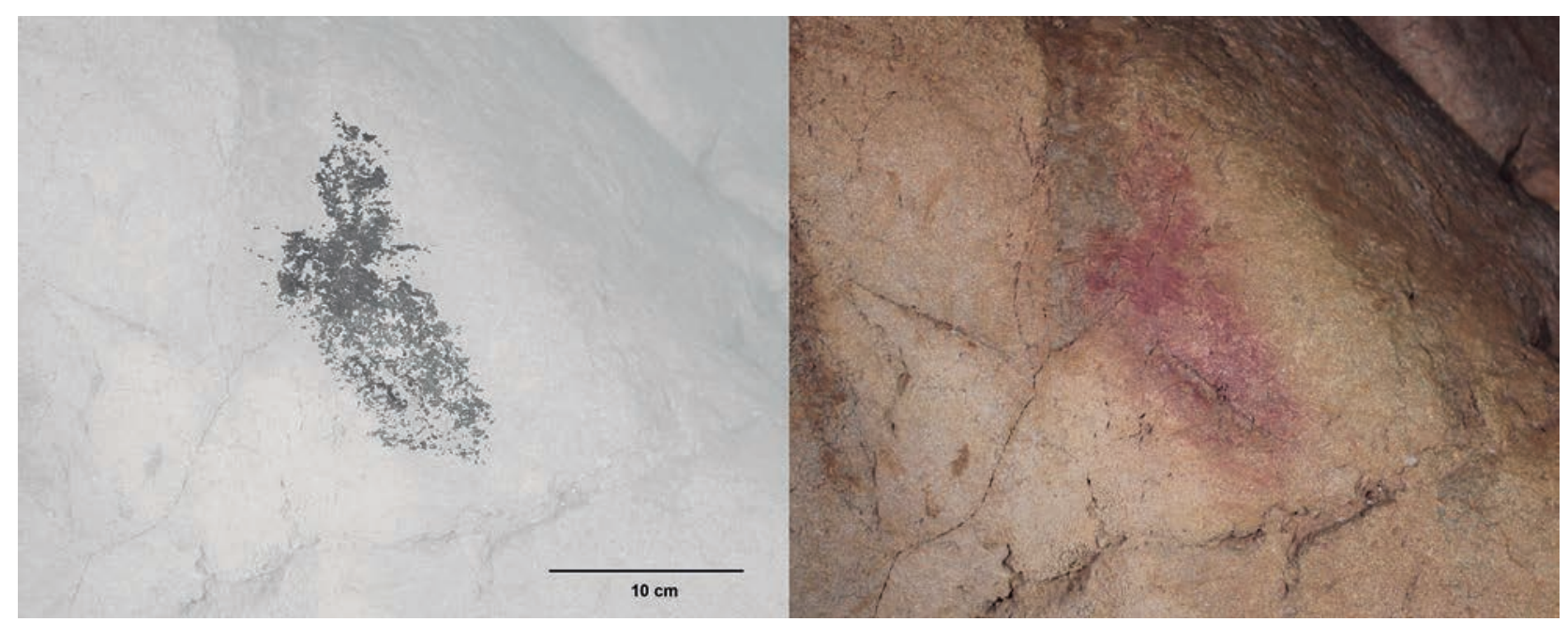

Fig. 2. Digital tracing and photo of graphic unit 1. / Calco digital y fotografía de la unidad gráfica 1. 


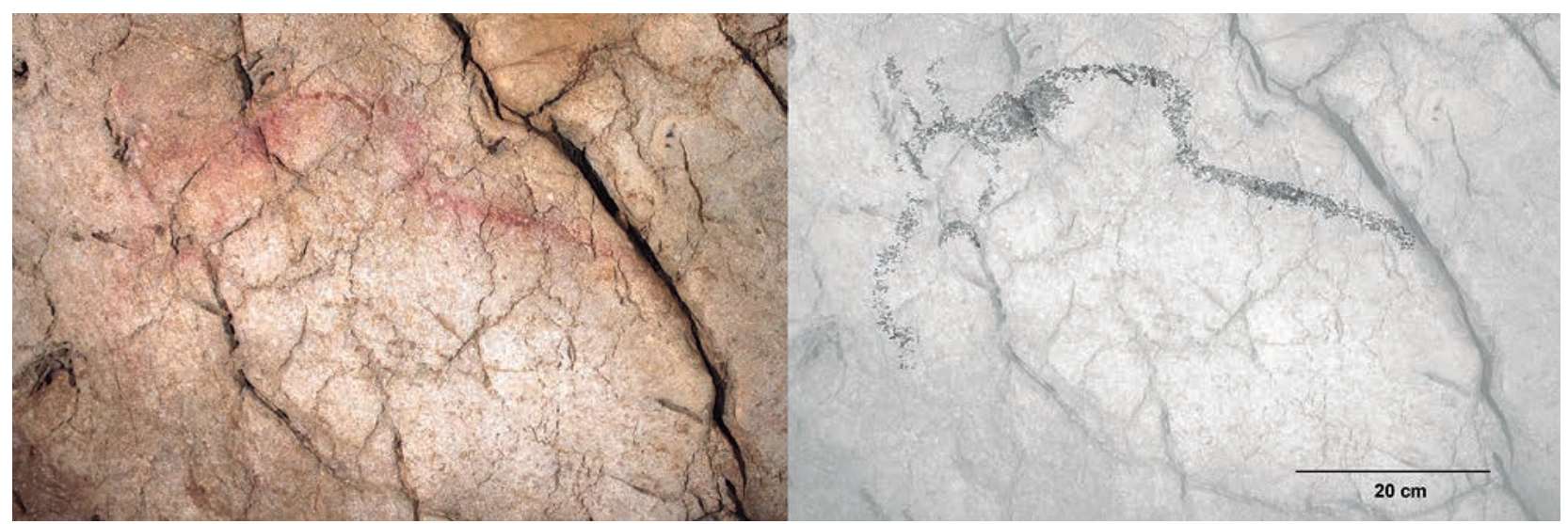

Fig. 3. Digital tracing and photo of graphic unit 3. / Calco digital y fotografía de la unidad gráfica 3.

Graphic unit 4. Located on the right-hand wall, $75 \mathrm{~cm}$ from the previous graphic unit, $114 \mathrm{~cm}$ above the floor and 170m from the junction. The limestone wall is vertical and the surface is flat and rough.

In this concentration of pigment, the colorant is distributed over a maximum area $5 \mathrm{~cm}$ wide and $8.5 \mathrm{~cm}$ high. The shape defined is round but irregular and the state of conservation is deficient. The technique used was drawing in red.

\section{RESULTS AND DISCUSSION}

Four graphic units have been documented: two concentrations of colour, a figurative depiction of a bison and a pseudo-triangular-shaped geometric form.

The figure of a bison was drawn in red but the state of conservation does not allow the medium of its application to be discerned. Its formal and stylistic characteristics are: modulated outline, coherent perspective of the horns, massive representation of volume in the frontal part of the animal, stressing the step between the hump and the dorsal line, and attention to some anatomical details: representation of the eye or eye socket in a crescent shape, the mass of hair or 'bun' (chignon in French), and the way of representing the frontal line.

Graphic unit 1 is a dense concentration of pigment with an approximately pseudo-triangular shape that has been interpreted as a geometric sign filled with colour. Similar examples can be seen in other parts of the cave such as Auntzei and the southern part of the Erdibide passage.

The rest of the ensemble consists of red pigment remains forming concentrations in a deficient state of conservation. However, they do not seem to belong to figurative depictions or geometric motifs.

This has been a significant discovery as the bison is now the first figurative graphic unit in the cave and this modifies the plan or structure of the graphic ensemble as it has been understood until now. Previously the first representation was the horse at the entrance to Auntzei Passage, which was interpreted as announcing that the cave was a 'sanctuary' dedicated to horses.

However, bison are not new in Ekain Cave. After the discovery of another two examples in Zaldei gallery (González-Sainz, 1999; Garate et al., 2015) and a re-interpretation in Azkenzaldei (Ochoa et al., 2018), eleven are known in the cave, distributed throughout all its sectors. A further three graphic units may also represent bison but these are cervical-dorsal lines that are hard to interpret. Altuna and Apellániz (1978) noted that all the bison figures are incomplete although only the lower part of the limbs is missing in some cases. This observation continues to be valid after the new discoveries, which are limited anatomically to the frontal part and/or the upper part of the animal.

A significant difference is seen between the bison and the horses in their technical treatment. The bison are generally represented in a simpler way: in black (in eight figures), red (two figures) and engraved (one scraped and one engraved with a finger on clay) (Fig. 4). Only one of them is technically elaborate: a bison in the main panel with a black outline, interior filled with red paint and also engraving in the area of the hump (Fig. 4D). However, from the stylistic point of view it is similar to the others with hardly any interior details. Contrasting with these technical and compositional procedures, the horses are more often represented complete, they are more naturalistic in the stylistic aspect and they employ multiple techniques, even the use of two colours and engraving in a single figure, in order to represent different kinds of interior fill (such as the ventral 'M'-shape) or such details as the eyes, stripes, hoofs, etc. They are more numerous in Ekain and the bison appear to complement them. As pointed out by González Sainz et al. (1999), this differs from other sites in northern Spain (Covaciella, Altamira, Santimamiñe and Altxerri caves, among others), where bison are more abundant and technically more elaborate and seem to be complemented by horses that are depicted more simply in their technique and style. 


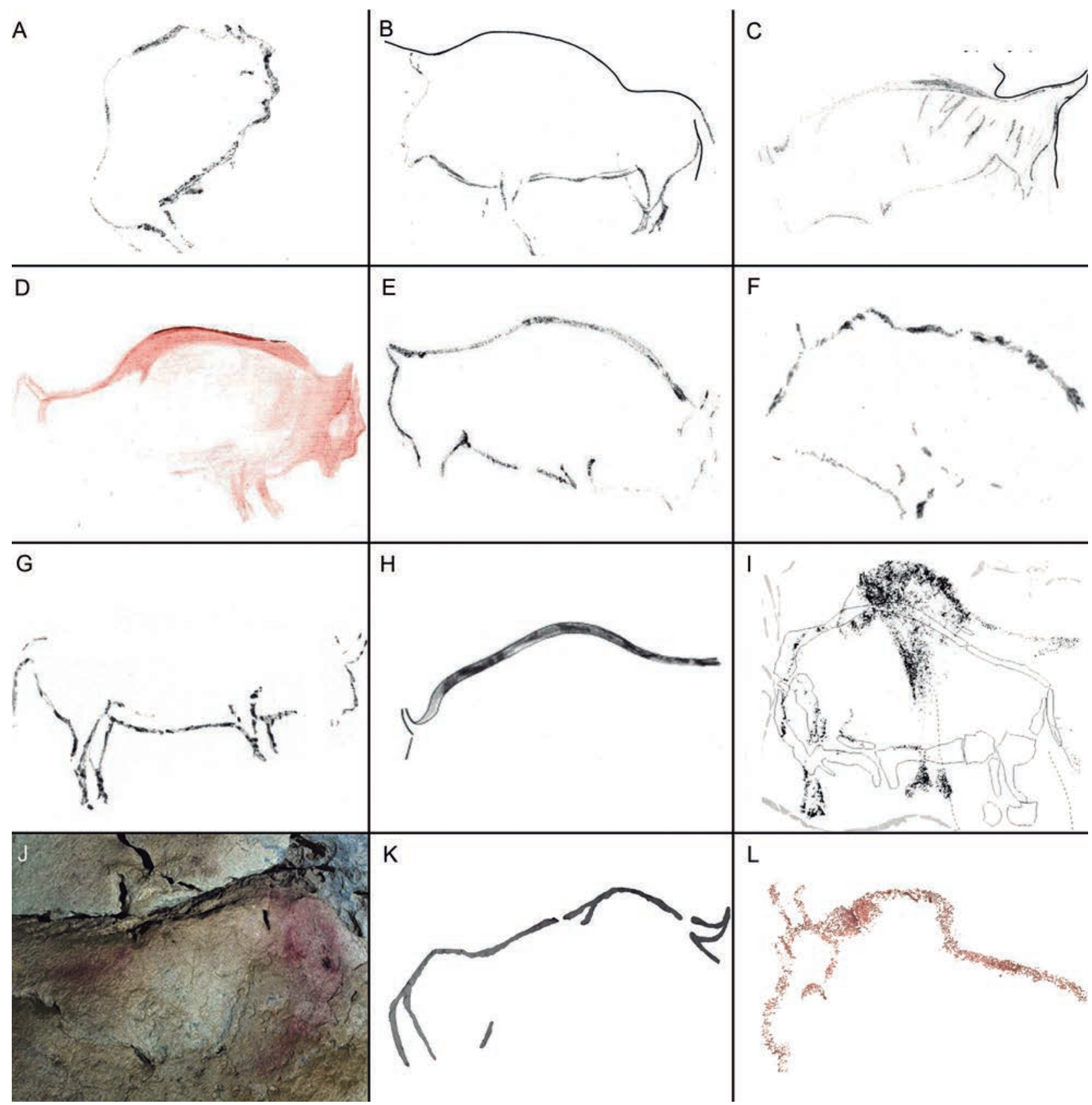

Fig. 4. Bison represented in Ekain cave (not to scale): A to H modified from Apellaniz and Altuna, 1978. A) 12, B) 14 . C) 17 , D) 18 , E) 19 F) 23 G) 35 H) 47 ; I) $25 \mathrm{~b}$ (modified from González-Sainz et al. 1999); J) photo from Garate et al. 2015; K) modified from Ochoa et al. 2018; L) Erdibide bison. / Bisontes representados en la cueva de Ekain (no a escala): A a H modificado de Apellaniz and Altuna, 1978; A) 12, B) 14, C) 17, D) 18, E) 19 F) 23 G) 35 H) 47; I) 25b modificado de González-Sainz et al. 1999; J) Garate et al. 2015; K) modificado de Ochoa et al. 2018; L) bisonte de Erdibide.

The stylistic characteristics of the bison discovered in Erdibide Passage suggest that it corresponds to the Niaux morphotype (Fortea et al., 2004). This same type has been identified in other parts of the cave; in Erdialde, on the block in the centre of the chamber (Fig. 4A), and in Zaldei (Fig 4 B to I). This style was produced in a particular time, with a wider distribution covering the south of France and the north of the Iberian Peninsula, and to a lesser extent they reach the centre of France. They are associated with a period of time between the end of the Lower Magdalenian and the Late Magdalenian (García-Diez et al., 2016).

A relative chronology can be established for the bison in Ekain cave. An engraved figure in a similar style to the new bison in Erdibide Passage and located in the main panel in Zaldei is superimposed on at least one of the bichrome horses (No. 25 in the classification of Altuna and Apellaniz, 1978). The order in which they were produced, as established by González-Sainz and colleagues (1999) after the discovery of this bison, was: 
first Figure 25a, an incomplete horse; then No. 25, one of the bichrome horses; and finally, the bison, engraved with very fine multiple lines (Fig. 4 I). However, it is difficult to determine the time elapsed between the depiction of the horse and the bison. Bearing mind, the chronology established for the two kinds of representations in similar rock art sites, it is very likely that they were synchronous in cultural terms, meaning both pertained to the same Magdalenian phase but might not be, in fact, strictly synchronic.

The comparison of this new graphic unit with the example on the so-called 'horse-rock' (No. 12; Fig. 4A) in Erdialde chamber is of particular interest. They both possess an eye, or possibly eye-socket, in the shape of a crescent. Both figures exhibit similar characteristics to the bison in Niaux cave (i.e. graphic units 52, 68, 81 and 102 -Clottes, 2010-), Santimamiñe (i.e. graphic unit 437 -González-Sainz and Ruiz-Idarraga, 2010-), Urdiales (i.e. graphic unit 9 -Montes et al., 2005-).

Garate et al. (2015: 289, Fig. 7) identified another bison, also in red, opposite the main panel of Ekain (Fig. 4J). This discovery is equally significant stylisticaIly, as it is a Font-de-Gaume type of bison, characterised by the massive fore-quarters, large hump and hair bun, prominent beard and drawn with a very modulated line (Fortea et al. 2004; García-Diez et al. 2016). The depiction of both bison morphotypes in the same cave is not very common in northern Spain, but occurs in Covaciella, La Pasiega, El Pindal and possibly in Urdiales, as well as in France at Rouffignac, Combarelles and possibly Font-de-Gaume and Niaux (García-Diez et al., 2016).

\section{CONCLUSIONS}

The find of this new decorated panel in Ekain Cave enriches our knowledge of Palaeolithic societies in northern Spain. The new methodologies available to archaeologists nowadays make the review of already researched and published cave art ensembles imperative. The combination of new methods with the acquired knowledge during the last decades are allowing to discover new depictions in caves that have been known traditionally, allowing to complete the 'map' and opening new possibilities for dating and advancing on the understanding of Upper Palaeolithic societies. Some of these discoveries might seem trivial, however, further research might prove their impact in the study of cave art. In the case of Ekain, the figure of the bison increases the catalogue of bison figures in the cave. It corresponds to the Niaux morphotype, which also appears in other parts of the cave and at other sites in the region. This type of bison is indicative of the graphic territories and long-distance networks of contacts that existed over a very large geographic area in the Middle and Late Magdalenian (Fortea et al., 2004; García-Diez, Ochoa, Vigiola-Toña, Garrido, \& Rodriguez-Asensio, 2016).

\section{ACKNOWLEDGEMENTS}

This study was carried out in the framework of the Prehistory Research Group at the UPV/EHU (IT-122319) funded by the Basque Government and the Spanish Ministry of Science projects HAR2014-53536-P and HAR-2017-82483-C3-P. Blanca Ochoa benefits from the Post-doctoral programme for the Training of Doctor Research Personnel, also funded by the Basque Government. The fieldwork was carried out thanks to the authorisation of research by the Department of Culture, Tourism, Youth and Sport in the Diputación Foral de Gipuzkoa and of access by the Cultural Heritage Centre of the Basque Government. The authors are also grateful for the assistance of Armando Llamosas, Mertxe Urteaga and Carlos Olaetxea.

\section{REFERENCES}

Altuna, J., 1997. Ekain y Altxerri: dos santuarios paleolíticos en el País Vasco. Haranburu, San Sebastián.

Altuna, J., Apellaniz, J.M., 1978. Las figuras rupestres paleolíticas de la cueva de Ekain (Deva, Gipuzcoa). Munibe Antropologia-Arkeologia 30.

Altuna, J., Mariezkurrena, K., 2008. Nuevos hallazgos en la cueva de Ekain (Guipuzkoa, País Vasco). Zephyrus 61, 17-32.

Altuna, J., Merino, J.M., 1984. El yacimiento prehistórico de la cueva de Ekain (Deba, Guipúzcoa). Eusko Ikaskuntza, San Sebastián.

Barandiarán, I., 1974. Representaciones de caballos en la cueva de Ekain. Estudios de Arqueología Alavesa 6, 47-56.

Barandiarán, J.M., Altuna, J., 1969. La cueva de Ekain y sus figuras rupestres. Munibe, 21, 329-386.

Clottes, J., 2010. Les cavernes de Niaux. Art préhistorique en Ariège. Errance, Paris.

Fortea, F. J., Fritz, C., García, M., Sanchidrián, J. L., Sauvet, G., Tosello, G., 2004. L'art parietal paleolithique a l'epreuve du style et du carbone-14. In: Otte, M. (Ed.), La Spiritualité. Actes du Colloque de La Commision 8 de I'UISPP (Paleolithique Superieur). Liege. (10-12 decembre 2010). ERAUL 106.

Garate, D., Rivero, O., Ruiz-Redondo, A., Rios-Garaizar, J., 2015. At the crossroad: A new approach to the Upper Paleolithic art in the Western Pyrenees. Quaternary International 364, 283-293. https://doi.org/10.1016/j.quaint.2014.05.054.

García-Diez, M., Ochoa, B., Vigiola-Toña, I., Garrido, D., Rodriguez-Asensio, J. A., 2016. Temps et réseaux de l'art paléolithique : la grotte de La Covaciella (Asturies, Espagne). L'Anthropologie 120(5), 588-609. https://doi.org/10.1016/j.anthro.2015.11.001

García-Diez, M., 2009. Palaeolithic caves of northern Spain: World Heritage Site. Rock Art Research 26(1), 99-101.

García-Diez, M., Ochoa, B., 2013. Arte Prehistórico. In: García-Díez, M., Zapata, L. (Eds.), Métodos y técnicas de análisis y estudio en arqueología prehistórica. De lo técnico a la reconstrucción de los grupos humanos, 611-634. Universidad del País Vasco, Bilbao.

González-Sainz, C., Cacho, R., Fukuzawa, T., 2003. Arte paleolítico en la región cantábrica: base de datos multimedia 
Photo VR. Universidad de Cantabria. Gobierno de Cantabria, Santander.

González-Sainz, C., Cacho, R., Altuna, J., 1999. Una nueva representación de bisonte en la cueva de Ekain (País Vasco). Munibe Antropologia-Arkeologia, 51, 153-159.

González-Sainz, C., Ruiz-Idarraga, R., 2010. Una nueva visita a Santimamiñe Precisiones en el conocimiento del conjunto parietal paleolítico. Diputación Foral de Bizkaia, Bilbao.

Montes, R., Muñoz, E., Morlote, J.M., 2005. Cueva Urdiales (Castro Urdiales, Cantabria). Estudio geo-arqueológico y arte rupestre paleolítico. Concejalía de Medio Ambiente y Patrimonio Arqueológico, Castro Urdiales.

Ochoa, B., Vigiola-Toña, I., García-Diez, M., Garrido, D., 2018. More than horse paintings in Ekain Cave (Deba, Gipuzkoa): Palaeolithic digital engravings in Western Europe. Trabajos de Prehistoria 75(1), 146-154. https://doi.org/10.3989/ tp.2018.12208 